Meta

Journal des traducteurs

Translators' Journal

\title{
Culture-Bound Collocations in Bestsellers: A Study of Their Translations from English into Turkish
}

\section{Yeşim Dinçkan}

Volume 55, numéro 3, septembre 2010

URI : https://id.erudit.org/iderudit/045065ar

DOI : https://doi.org/10.7202/045065ar

Aller au sommaire du numéro

Éditeur(s)

Les Presses de l'Université de Montréal

ISSN

0026-0452 (imprimé)

1492-1421 (numérique)

Découvrir la revue

Citer cet article

Dinçkan, Y. (2010). Culture-Bound Collocations in Bestsellers: A Study of Their Translations from English into Turkish. Meta, 55(3), 456-473.

https://doi.org/10.7202/045065ar
Résumé de l'article

Le présent article traite des collocations culturellement marquées dans les traductions en turc de trois best-sellers anglais récents. Les résultats de l'étude sont présentés en fonction de la nature des exemples et de la stratégie de traduction, et sont discutés en référence au cadre conceptuel de la naturalisation et de l'étrangéisation. Sont abordés l'étude des facteurs qui peuvent influencer le travail du traducteur tels que le contexte, les exigences de la maison d'édition et le type de roman traduit, ainsi que les liens entre best-sellers, culture populaire et traduction. Une réflexion sur la cohérence et le choix de stratégies de traduction et l'établissement d'une liste de onze facteurs à prendre en considération pour la traduction de best-sellers concluent l'étude. Il est suggéré que la langue source (l'anglais) et le type de roman (best-seller) ont dû influencer les choix opérés par les traducteurs. L'article se termine par un ensemble de suggestions pour la traduction de best-sellers ainsi que par une invitation faite aux théoriciens de la traductologie à se pencher non seulement sur les classiques de la littérature mais également sur les fictions populaires.
Ce document est protégé par la loi sur le droit d'auteur. L'utilisation des services d'Érudit (y compris la reproduction) est assujettie à sa politique d'utilisation que vous pouvez consulter en ligne.

https://apropos.erudit.org/fr/usagers/politique-dutilisation/ 


\title{
Culture-Bound Collocations in Bestsellers: A Study of Their Translations from English into Turkish
}

\author{
YEŞIM DINÇKAN \\ Hacettepe University, Ankara, Turkey \\ ydinckan@hacettepe.edu.tr
}

\begin{abstract}
RÉSUMÉ
Le présent article traite des collocations culturellement marquées dans les traductions en turc de trois best-sellers anglais récents. Les résultats de l'étude sont présentés en fonction de la nature des exemples et de la stratégie de traduction, et sont discutés en référence au cadre conceptuel de la naturalisation et de l'étrangéisation. Sont abordés l'étude des facteurs qui peuvent influencer le travail du traducteur tels que le contexte, les exigences de la maison d'édition et le type de roman traduit, ainsi que les liens entre best-sellers, culture populaire et traduction. Une réflexion sur la cohérence et le choix de stratégies de traduction et l'établissement d'une liste de onze facteurs à prendre en considération pour la traduction de best-sellers concluent l'étude. Il est suggéré que la langue source (l'anglais) et le type de roman (best-seller) ont dû influencer les choix opérés par les traducteurs. L'article se termine par un ensemble de suggestions pour la traduction de best-sellers ainsi que par une invitation faite aux théoriciens de la traductologie à se pencher non seulement sur les classiques de la littérature mais également sur les fictions populaires.
\end{abstract}

\begin{abstract}
This paper discusses the treatment of culture-bound collocations in translations of three recent English bestsellers into Turkish. The findings are categorized as per the nature of the example and translation strategy, and they are further discussed within the framework of domestication and foreignizing. Factors that may affect translators, such as context, the demands of publishers in Turkey and the genre of the novels - bestsellers - and the relations between best-sellerization, popular fiction, and translation are also discussed. The conclusion includes reflections concerning the consistency in the choices of translators, the least preferred strategies and eleven factors that may affect the translators of bestsellers. It is argued that the fact that the source language is English and the source books are bestsellers have affected the choices of the translators. In conclusion, some suggestions in reference to the translation of bestsellers are made and it is emphasized that not only translations of classical literature, but also of popular fiction constitute a fruitful field of study for translation scholars.
\end{abstract}

\section{MOTS-CLÉS/KEYWORDS}

collocations culturelles, best-sellers, fictions populaires, stratégies de traduction, naturalisation, étrangéisation

culture-bound collocations, bestsellers, popular fiction, translation strategies, domestication, foreignizing

\section{Introduction}

"It is actually striking that a great deal of what has passed as traditional translation theory has in fact been restricted to literary translation" (Chesterman and Wagner 
2002: 18). Chesterman and Wagner (2002: 4) confess that translation theory has mostly concentrated on literary translation, but the catch is that it should be noted that the term literary translation used in that context is mostly restricted to classical literature. They justify the importance given to literary translation with the following words: "literary translation has traditionally had a high status, after all: such texts are seen as Culturally Important" (Chesterman and Wagner 2002: 18). On the other hand, it is clear that not only classical literature, but also the translations of popular fiction are culturally important and worth studying. Eco claims that,

[i]f translation studies are concerned with the process of translation from a source text A in a language Alpha to a target text B in a language Beta, then translation scholars should have had, at least once in their life, both the experience of translating and that of being translated [...] (Eco 2001: 5).

The relationship between theory and practice has been a subject of discussion in translation studies for a long time. It is true that practice feeds the former and theory tries to understand the nature of the field of study through observation and empirical data. Though not specifically designed for it, theoretical knowledge may also provide insight for practising translators and students of translation. As Eco suggests, one way of doing this is to dwell on the problems that the researcher faces in his/her personal experiences as a translator and observe various data in the related field.

The scarcity of such resources in the field of translation of popular fiction has been brought to my attention during both my own practices as a translator, translation scholar and teaching as a lecturer. Paizis (1998), Linder (2001) and Mercer (2001), who also used popular fiction as their corpus of data in translation analysis, similarly complain about the lack of academic interest in the field. I know from my own experiences as a translator of both classical literature and popular fiction that several features of novels in the popular fiction genre, such as the purpose of the text (e.g., to entertain), the demands of the publishing houses (e.g., to consider sales), the difficulties that arise (e.g., use of colloquial language, allusions to popular culture, language of intimacy, etc.) and the strategies to be used (e.g., footnotes are not favoured in the translation of bestsellers by the publishing houses) may differ from the translation of classical literary texts.

Therefore, I thought it may be fruitful to carry out research on this topic and use my experience as a translator in the field as a starting point. The first article I wrote on the translation of bestsellers concentrated on the novels I have translated and it focused on the problems that may arise during the translation of popular fiction (Dinçkan 2006). ${ }^{1}$

The purpose of this second study is to analyze culture-bound collocations and their translations in the bestseller novels, namely; Bridget Jones's Diary by Helen Fielding (2001), translated by Dost Körpe and Handan Hazar (2004), ${ }^{2}$ About a Boy by Nick Hornby (2000), translated by Esin Eşkinat (2005), ${ }^{3}$ and Black \& Blue by Ian Rankin (1998), translated by Zeynep Perker (2006). ${ }^{4}$ The publishing houses of the translations are Gendaş Kültür, Sel Yayıncılık and Vatan Kitap respectively. One of the important points to be mentioned about these three publishing houses is that they publish not only translation of bestsellers, but also books on social sciences, Turkish literature, children's literature, and several other fields. It would not be wrong to say that most of the publishing houses in Turkey try to finance their other series of books through the profits they expect to earn from translated bestsellers. 


\section{The need for a study of the translation of popular fiction from English into Turkish}

In recent years, the products of popular fiction, especially bestsellers, have been translated widely from English into Turkish; the cultural features in these novels reach many readers through language use in translated novels.

New genres and new styles of fiction have been added to Turkish literature through translated literature. Some examples of genres further incorporated into Turkish literature are detective stories, fantasy and popular women's literature. Approximately seventy percent of these translations into Turkish are from English (Kurultay, Ayav et al. 1992: 150) and books written by American and/or British authors predominate among these translations [...] (Dinçkan 2006: 108).

This situation is probably also prevalent in other cultures, and thus not specific to Turkey. Venuti (1995: 14) also calls our attention to this point with the following words: "Since World War II, English has been the most translated language worldwide, but it isn't much translated into." The significance of this and how it may affect the choices of the translators during the translation of English cultural collocations in terms of foreignization and domestication will be dealt with in the latter half of the study.

As Chesterman and Wagner state:

One of the best contributions translation scholars can make to the work of professional translators is to study and then demonstrate the links between different translation decisions or strategies, and the effects that such decisions or strategies seem to have on clients and readers and cultures, both in the past and in the present, under given conditions (Chesterman and Wagner 2002: 5).

Therefore, as stated earlier, the translations of this genre, its specific problems, and the strategies used by translators to overcome them, are well worth studying.

\section{Bestsellers}

Since the corpus of data of the study is composed of British bestsellers and their translations into Turkish, it is essential to set the limits of the study and define the bestseller genre.

In theory, a bestseller may be simplistically defined as a work of fiction sold in the most units to the most people over a set period of time. In practice, the definition is complex, running into difficulties as to the definition of units (hardback; paperback; serialisation) and period of time (month of publication; a year; the twentieth century), the importance of the price at which it is sold and the definition of fiction itself (whether the work is literary, popular, pulp) (Bloom 2002: 6).

Furthermore, Hinckley and Hinckley who have carried out a research on 486 American bestsellers and 216 authors in a 20 -year period inform us that

[...] they range from serious literature to highly intelligent escape reading, on through the ranks of formula fiction to drivel. The characters are as diverse as the themes and categories. There is a striking diversity among the authors, too. Bestsellers are written by former vice-presidents, Nobel Prize winners, missionaries, and scientists; elderly ladies, farm girls, and feminists; lawyers, teachers, and cops (Hinckley and Hinckley 1989: 3). 
It is true that bestsellers are generally characterized by their sales rates or short shelf-life and share certain characteristics in their characters and plots - however stereotyping bestsellers may not always be correct.

If stereotyping bestsellers is problematic, drawing a dividing line between bestseller and popular fiction is even harder. Bloom (2002) warns us that the terms bestseller and popular fiction, though mostly used interchangeably, do not necessarily mean the same thing.

Any study of best-selling fiction is also a study of popular literature in its broadest sense, but a study of popular literature is a broader concept than the more narrow one of the bestseller and covers a wide range of ideological (especially sociological, political and aesthetic) areas of which the bestseller is only one acute example. Popular literature and the analogous area, popular fiction, need therefore no necessary relationship to mass sales; rather they act as a focus for the intermixture of sociological and political questions, expressed through aesthetic means, found in the mass consumption of culture. The best-seller, appropriately, reaches the most readers and is therefore, almost by accident, popular in the sense given above. 'Popular' literature defines a perceptual arena, a field out of which the bestseller emerges. This field includes fiction that may not sell well at all. A bestseller can never be clearly predicted (and is therefore a type of necessary but reassuring 'sport' of popular literary production) (Bloom 2002: 17).

Radford (1986: 3-5) also refers to the subject and explains that [t]he term 'popular' is itself a notoriously unstable category, one which has not only undergone changes in meaning since its derivation from the Latin 'popularis' (belonging to people), but which is in its present usage ambiguous, having accumulated a number of contradictory senses of both a positive and negative kind. The categories high/low and popular/art are thus interdependent and shifting, so what is being designated or distinguished changes from period to period according to a wider set of social practices and institutions. So, for example, what is popular in its own period may become Art in another. In fact arguments which dichotomise Literature/popular writing as a simple opposition have come under increasing challenge. Not merely because of the evident inadequacy of popular equals bad, escapist side of the antithesis, but also because the notion of 'Literature,' as an order of 'timeless monuments' or eternal truths, has itself broken down.

As can be seen from the above summarized discussions, though the terms seem self-explanatory at first glance, it is not easy to define the terms bestseller and popular fiction. The definition of the term bestseller in Merriam Webster's Reader's Handbook (1997: 58-59) is: "a book that, for a time, leads all others of its kind in sales, a designation that serves as an index of popular literary taste and judgement"; this suggests that a bestseller may also be considered as the reflection of popular taste, though there may be contradictory discussions or examples which fall outside these definitions. It should be noted that for practical purposes the term bestseller will be used throughout the study for examples of popular fiction which are or have been popular and widely sold or assumed to be read for a certain period.

\subsection{The characteristics of bestsellers}

Among others, the most important feature of bestsellers for the purposes of this paper is that they seem to reflect everyday life and popular culture rather more closely than 
any other genre. Bloom also underlines this characteristic of the genre with the following words:

Popular fiction releases a desire in language to become the very life that is being portrayed by it. Here language looks beyond itself and into the world, but a world already distributed and arranged according to the geometry of its own trajectory, its own abstract needs, now striving for materialisation: fiction as lifestyle (Bloom 2002: 21).

Another characteristic of bestsellers to be mentioned within the scope of the study is explained by Bloom with the following words:

Popular fiction (all fiction) vanishes because it has a limited shelf life. It must be constantly reinvented (transferred to new media) if it is to retain freshness and this is true for content as it is for things as central and yet 'invisible' as 'typographic setting' (Bloom 2002: 16).

Here it should be borne in mind that the principal aim of bestsellers is commercial and preservation of popularity (also known as high sales rates) is an important feature.

Only in its translation into another medium can popular fiction find itself again returned in a continuous loop of renewal because it is never complete in itself. In seeking its own absolute limit the art novel enwraps itself within itself: Untranslatable, irascible, and sublime. Popular fiction always seeks other partners (Bloom 2002: 20).

Translating a bestseller into another language is also a way of transferring it to another medium, to another market and to different readers.

\subsection{Translation of bestsellers}

The translation of bestsellers is a widespread practice and is of interest both to the translator and of course publishing houses:

Publishers can decide to promote a book into a top seller, with the publicity tours arranged before the manuscript is done. Still some books that are vigorously promoted do not sell well; the same authors do better with some books than others [...] (Hinckley and Hinckley 1989: 11).

On the other hand, it would not be wrong to say that where the translation of a book is concerned, publishers generally choose among the acclaimed bestsellers in the source language rather than random examples of popular fiction. They also try to promote the translated version yet may end up with low sales rates unlike the original. Nonetheless, during the translation process the book is considered as a bestseller candidate and expectations are determined accordingly.

The translator of a bestseller then may have additional tasks due to time limitations, film adaptations, wide-readership and promotional campaigns. The sales rates of any translated book are now becoming a major preoccupation of most publishing houses and translation scholars suggest that the translation choices made by the translators of bestseller novels are now under more pressure concerning sales.

Mercer also points out the differences between the translation of classical literary texts and popular fiction, stating that:

Popular novels tend to be both written and read more quickly and with less concentration than more literary works. Therefore (with reference to the original author, the 
translator, and the reader of both the ST and TT), the language itself, whilst not necessarily easier or sloppier was not intended to be savoured and analysed to the same extent. Its primary purposes are readability and maintaining narrative and emotional tension. This makes it neither better nor worse than the language of more canonical texts, but different. So it is reasonable that the approach to translation should also be different (Mercer 2001: 35).

However, here we must note that the re-translation of classical texts has also become a profitable business and classical texts may also be retranslated more rapidly and sales concerns may also affect the publishers and translators, thus not limiting the approach referred to as being only valid for the bestseller genre.

Venuti (2004), who is one of the few scholars to broach the topic of translation of bestsellers in his book, further discusses the issue from a more ideological point of view:

The imagined communities fostered by translation produce effects that are commercial, as well as cultural and political. Consider, for example, the mass audience that gathers around a translated bestseller. Because of its sheer size, this community is an ensemble of the most diverse domestic constituencies, defined by their specific interests in the foreign text, yet aware of belonging to a collective movement, a national market of a foreign literary fascination. These constituencies will inevitably read the translation differently, and in some cases the differences will be incommensurable. Yet the greatest communication gap here may be between the foreign and domestic cultures. The domestic inscription in the translation extends the appeal of the foreign text to a mass audience in another culture. But widening the domestic range of that appeal means that the inscription cannot include much of the foreign context. A translated bestseller risks reducing the foreign text to what domestic constituencies have in common, a dialect, a cultural discourse, an ideology (Venuti 2004: 496).

The translator walks the thin line between the source text and the translation: on the one hand he / she trying to reflect the culture-specific features of the source text, and on the other hand making sure that the translators' version stands on its own feet as a work in the target culture.

\section{Collocations}

In an attempt to further narrow the corpus of data at this juncture it would be appropriate to introduce the subject of collocation. Collocation can be defined as the tendency of certain words to co-occur regularly in a given language. At one level, the tendency of certain words to co-occur has to do with their propositional meanings. For example, cheque is more likely to occur with bank, pay, money, and write than with moon, butter, playground or repair. However, meaning cannot always account for collocational patterning. If it did, we might expect carry out, undertake or even perform to collocate with visit. Yet, English speakers typically pay a visit, less typically make a visit, and are unlikely to perform a visit (Baker 1992: 47).

There are no written rules concerning the use of collocations in a language. However one recognizes an unusual collocation immediately in one's native language. Bahumaid also defines collocations as

[...] kinds of "fixed expressions" or "set phrases" which are subjected to some 'selection restrictions.' As is the case with idioms, none of the elements of a collocation can be 
replaced by another lexical item even if they have a similar meaning (e.g., long and tall are synonymous yet one would say a tall man but not a long man). Moreover, many collocations share with idioms the two features of unpermitted permutations or insertion of additional elements within the collocating items. Unlike idioms, however, the meanings of the elements of a collocation are reflected in the meaning of the collocation as a whole (Bahumaid 2006: 133).

Though the translation of collocations may be problematic during translation, personal experience has led me to consider culture-bound collocations as the most troublesome, thus the study focuses on collocations with cultural connotations.

\subsection{Culture-bound collocations}

Dealing with culture-bound collocations are an important issue in the translation of literature in general and bestsellers in particular.

Some collocations reflect the cultural setting in which they occur. If the cultural setting of the source and target languages are significantly different, there will be instances when the source text will contain collocations which convey what to the target reader would be unfamiliar associations of ideas. Such culture-specific collocations express ideas previously unexpressed in the target language. Like culture-specific words, they point to concepts which are not easily accessible to the target reader [...] (Baker 1992: 59-61).

For example, there is not any corresponding form for the English collocation happy hour in Turkish. Although a few bars reduce their prices and introduce several activities in the afternoons and put happy hour sign on their windows and menus, the English collocation happy hour is used in these signs. Such examples of culturebound collocations appear frequently in popular fiction as they reflect everyday life and culture. At this juncture, it should be noted that the nature or the formality of culture-bound collocations may differ from the ones in classical literary texts and may challenge the translator of bestsellers.

\subsection{Translation of culture-bound collocations in bestsellers}

The translation of culture-bound collocations may be problematic. When one is translating from one's native language (A) into a foreign language (B) the appropriate use of collocations may be a problem. In translating from one's B language into one's native language, as in this study, recognition of culture-bound collocations, understanding the meaning and connotations of each, and rendering them into target language may be the most challenging tasks. For example, the collocation terraced housing may mislead the Turkish translator at first glance since it refers to a row of joined houses in English, whereas it may be understood as houses with terraces if the translator does not know the meaning of the culture-bound collocation and fails to realize that this is a collocation rather than an unlexicalised noun phrase. In reference to this example of the recognition of culture-bound collocations, understanding meaning and connotations and rendering them into target language may be one of the most challenging tasks.

Another important point to be mentioned at this juncture about translation of bestsellers is that the translator is always translating something with a deadline. 
When a book becomes a bestseller the publishing house which procures the translation rights of the said novel wants to publish it as soon as possible. The advertisements, book reviews, prizes, screen adaptations, and the publicity of the bestseller all contribute to sales rates. So the translator of bestsellers should consider not only the deadline, but also aim not to hinder the pleasure and speed of reading for the target audience. These concerns should be kept in mind during the analysis of the choices made by the translators.

\section{Comparative Analysis}

The corpus (names of the novels and their translations are noted in section 1.) is not restricted to one specific genre of popular fiction (e.g., detective stories) because culture-bound collocations may occur in every genre of popular fiction, but considers whether the translation strategies differing from one genre to another may be a topic for a further study and falls outside the scope of this one. One of the concerns in determining the corpus of data was that each novel has been published by a different publishing house and translated by a different translator or translators. I thought this may be helpful in observing a wider range of choices in terms of the tendency of publishing houses and translators where the translations of bestsellers are concerned. Another concern was the date of publication of the novels; all four translated novels are published after the year 2000 and thus may display rather recent tendencies within the Turkish translation norms.

The novels chosen as corpus of data have been analysed comparatively in terms of the culture-bound collocations. First, all the culture-bound collocations and their translations have been located, then they are grouped according to the strategies used in their translations. Some recurring examples translated with the same strategies have been excluded from the study. The culture-bound collocations and their usages within the source culture have been researched both on the Internet and through discussions with native speakers in order to determine the appropriate translation strategies. Of course, the number of novels studied is not adequate to make generalizations about overall tendencies in the translation of bestsellers in Turkey; however I hope it may at least provide a glimpse of information on the subject within the given limitations.

\subsection{The translation strategies used in translating culture-bound collocations}

Culture-specific items and the translation strategies used to overcome problems are studied by various scholars such as Newmark (1988), Aixela (1996), Katan (2004), and Baker (1992). Though the concern of this paper is not culture-specific items at word level but those at collocational level, these studies provide valuable insights into the analysis of culture-bound collocations and the strategies used during the translation of bestsellers. Baker (1992) listed eight strategies used by translators encountering problems at word level and four for translating idioms. Some of these strategies (adapted to collocations) which are used by the translators of the bestsellers, plus the additional ones which I noted during the analysis will be used to classify the strategies employed during the translation of collocations. The strategies and what they refer to within this study are as follows: 
1) Translation using a loan collocation (preserving the source culture-bound collocation);

2) Literal translation (translating word-for-word);

3) Footnote;

4) Translation by paraphrase (explaining the meaning of the culture-bound collocation);

5) Translation by a collocation of similar meaning but dissimilar form;

6) Neutralization (translating the culture-bound collocation with a neutral form);

7) Translation by cultural substitution (this strategy involves replacing a culturespecific item or expression with a target-language item which does not have the same propositional meaning but is likely to have a similar effect on the target reader) (Baker 1992: 31);

8) Omission;

9) Mistranslation.

\subsection{Findings}

When the culture-bound collocations are grouped in terms of the categories of translation strategies used by the translators (see appendix), it is possible to list several observations before going into detail about the examples:

1) Nature:

a) Culture-bound collocations used in the bestsellers are usually related to daily life and are casual rather than historical or literary (though this might change if the novels analysed were historical);

b) The examples of culture-bound collocations used in the bestsellers may be broadly and non-exhaustively grouped under the cultural categories of food and beverages, special days and holidays, entertainment and leisure time activities, marital status, address terms and referring expressions, place names, household appliances, social habits and traditions, politics and institutions;

c) Culture-bound collocations used in bestsellers are not only problematic for the translator of bestsellers, since they are also frequently encountered in popular movies and television series, thus research on such linguistic use is of value for AV translators.

2) Translation:

a) A wide range of strategies are used to translate culture-bound collocations;

b) The same culture-bound collocation can be translated in a different way in a different novel;

c) A single culture-bound collocation can be translated in a different way even within the same novel;

d) Some of the culture-bound collocations already have widely recognized translations (i.e., spring roll - çin böreği) whereas some are borrowed into Turkish (i.e., happy hour).

3) Strategy:

a) Translation by non-cultural form is the most frequently-used strategy in the examples;

b) Footnote is only used once and it is the least preferred strategy in translating culture-bound collocations in the novels analysed;

c) Some collocations are translated by a combination of two strategies;

d) Long explanations about the cultural collocations in the text are not favoured. 


\subsection{Discussion of examples within the framework of foreignization and domestication}

As Snell-Hornby (2006: 147) points out, “[s]ince Venuti’s book appeared in 1995 the controversy of domestication vs. foreignization has taken a central position in the English-speaking Translation Studies debate." Although Venuti's ideas and discussions mainly focus on English as a target language and the Anglo-American culture as the target culture, it may be interesting to consider the above examples translated from English (source language / culture) into Turkish (target language / culture) within this framework. As can be observed in the examples (see Appendix), translators use both foreignizing and domesticating strategies when translating culturebound collocations in bestselling popular fiction from English into Turkish. The choices of the translators, in a way, reflect Mercer's view (2001: 98) on the issue: "the translator of popular novels has to tread a tightrope between domesticating and foreignizing."

As already stated, domesticating cultural collocations is easier and less timeconsuming and so where the translation of bestsellers is concerned it is not surprising that we see such choices due to the working conditions of the translators mentioned before. As Venuti (1998: 125) also says, "[a] bestselling translation tends to reveal much more about the domestic culture for which it was produced, than the foreign culture which it is taken to represent." On the other hand, when the examples of foreignization are considered it may be said that the prevailing effects of AngloAmerican culture in the world and thus in Turkey may have encouraged the translators in some of their choices; for example, in borrowing an allusion to a magazine like Cosmopolitan (a Turkish version being published in Turkey) and translating April Fool's Day by using a collocation of similar meaning but dissimilar form strategy, since the concept exists in Turkish and people know its significance. I doubt the translators from any other languages would or could translate the culture-bound collocations in the same fashion by taking for granted that the target readers are familiar with the collocation or the concept in question. However, it is important to note that although Turkish readers are familiar with some of these concepts the collocations are still foreign to them and thus make the readers aware of the fact that they are reading a translated novel, so they are still considered as examples of foreignization. Bearing this in mind, an overview of the strategies with reference to several examples may be appropriate.

In the examples from the analysis translation, using a loan collocation, literal translation, footnote, translation by paraphrase, and translation by a collocation of similar meaning but dissimilar form are considered as foreignizing strategies; whereas translation by non-cultural form, translation by cultural substitution and omission (the data given in the table has been sorted out according to this order) can be considered as strategies of domestication. There are examples of both domestication and foreignization in the mistranslation category. Though mistranslation may sometimes be intentional as a result of domesticating or foreignizing strategies used by the translators, the examples in this study seem rather unintentional.

In considering the examples under the category of translation using a loan collocation and literal translation, it may be noted that a foreignizing effect is achieved through either loan words or literally translated unusual collocations in the target 
language. Collocations such as some sort of Mary Poppins person (see example 1 in appendix) or Bank Holiday (ex. 2) are foreign to Turkish culture and it is difficult to grasp their meaning or highly unlikely even within the context. Though Bank Holiday, which is translated literally into Turkish, adds to the foreignization effect by puzzling the reader (if this was the aim of the translator), it may also be misunderstood as a holiday in which only banks are closed rather than an official holiday.

Translation by footnote (ex. 3), translation by paraphrase (ex. 4), and translation by a collocation of similar meaning but dissimilar form (ex. 5) may also be considered as foreignizing translation strategies where the examples in the study are concerned, since they also help to preserve the cultural difference of the foreign text rather than devising a text which is read like an original. For example, the collocation chip shop (ex. 4) referring to a shop selling fish and chips is translated as fish and crisp shop, the use of the word crisps is probably a mistranslation but what is important in this example is that a collocation used for a traditional British food is preserved and gives the reader a hint about the habits of the source culture. Fish and chip shop is a rather unusual collocation in Turkish since there are only a few restaurants serving the dish. However, there are no specific fish and chip shops, but only fish restaurants in Turkey. The target reader in this specific case may be further puzzled when he / she reads the mistranslation of the collocation as fish and crisp shop instead of fish and chip shop.

Neutralizing, deleting the cultural specificity and using a culturally unmarked culture-bound collocation is one of the techniques which is less time-consuming both for the translator and for the reader. The translator trying to meet a deadline and probably also wishing to produce a fluent text may prefer this strategy rather than struggling with dictionaries, on the Internet or with long footnotes. The assumed expectations of the readers of bestsellers and the importance of the culturebound collocation within the text become relevant at this point. For example, a man waiting in front of a charity shop (ex. 6) becomes a man waiting in front of a shop in the target text and this will focus the reader on the action of meeting rather than the cultural collocation a charity shop. Here it is important to note that the source reader will probably not focus on the collocation a charity shop (unless this has some intrinsic or implicational connotation within the text) which would be an exception to the case exemplified since it is a common type of shop in his / her culture. However, if the waiting had taken place in a charity shop or rather an important event in one of the bestsellers had taken place in a charity shop then the translation strategy used might have been different. It should also be noted that the translator's task would have been difficult in that case since the significance and connotations of charity shops in British culture might have required a rather long explanation.

When the examples of translation by cultural substitution are analysed, a certain degree of manipulation of cultural connotations may be observed. The culture-bound collocation single mother (ex. 7) is translated into Turkish in two different ways: one of them is as a mother who is alone and the second one is a widowed mother. It is also possible to add a third example which is used for a similar collocation single parents' group and it is translated as a club for divorced parents so the third alternative is $a$ divorced mother. None of them renders fully the status of a single mother as is relevant in the source culture; being a mother and not married at the same time and probably not having ever married. In fact the collocation may have been translated as bekar anne (a mother who is single) into Turkish if the literal translation strategy has been 
preferred; although the collocation is not a common one, the meaning may have been preserved. However, having children is usually (i.e., culturally, socially) directly associated with being married in Turkey and if a mother is living alone, she is either thought to be divorced or widowed. There are exceptional cases of single mothers of course, but it is very rare and generally frowned upon in polite society. The translator may either not know the connotations of being a single mother in the source culture or may have passed her own value judgements during translation or the publishing house and editor(s) may have censored the collocation and in this way manipulated the text and suited it to the assumed target audience expectations.

The strategy of omission is also a domesticating strategy in which the culturebound collocation disappears in the target text without leaving a trace. The collocation of Big Apple (ex. 8) for example is used for New York in English and in Bridget Jones's Diary. In one of the dialogues, Arabella asks Mark: Haven't seen you for yonks. How was the Big Apple? but somebody else speaks up and Mark cannot answer the question. In the Turkish translation Arabella says to Mark: Seni çok uzun zamandan beri göremiyorum. Nasılsın? (I haven't seen you for ages. How are you?). The translator may have thought there was no need to introduce a foreign element to the text; in this case since it only occurs once and may be considered not very important in the general outline of the said novel, as it is not one of the main events. However, using a non-cultural form (New York) is another alternative strategy of domesticating which the translator did not opt for.

The number of mistranslations is unfortunately high in the bestsellers studied. I encountered mistranslations not only in the translation of culture-bound collocations, but also in the translation of cultural words which are not included in the study. Once again, the deadlines, the amounts paid to the translators and sometimes the misconceptions about the assumed readers may be some of the underlying factors. The collocation smoked salmon (ex. 9) is translated as salmon fish in one context and as smoked trout fish in another context and they are both mistranslations. I do not think this is a conscious choice because there is not any significant difference among smoked salmon, salmon fish, and smoked trout fish in terms of their foreignness to the target reader. This collocation occurs in Bridget Jones's Diary and the reasons for there being not only mistranslations but two different translations in the same book may be the result of the work of a co-product of two translators. Examples of mistranslation both contain foreignizing elements like using terms like baseball, crisps and also domesticating elements as in the example of translating terraced housing as houses with terraces.

\section{Conclusion}

In discussing the range of strategies used in the analysed novels there seems to be no general consensus between the different translators as to which strategy is preferable in translating culture-bound collocations. Moreover, the translators are also not consistent in preferring one strategy over another in terms of the cultural categories of food and beverages, special days and holidays, entertainment and leisure time activities and the like. However, there seems to be a certain consistency in the choices of the individual translators in terms of foreignizing or domesticating the culturebound collocations through various strategies. This may be either the translator's 
own decision or the publishing house's policy for the translation of bestsellers or translated books. There is also a consensus as to which strategy is not preferable in translating culture-bound collocations in bestsellers (and it is): this is the use of footnotes, which only occur rarely.

The concepts of preferences and translators' choices should not only be taken to mean that the translator assessed the translation problem and made a wise / unwise acceptable or otherwise choice. What we as researchers view is the final product - also known as the printed novel. And it is clear in the Turkish market that this not only reflects the choice of the translator but that there are many other factors at play which either affect the translators' choices or affect the product. Some of these include:

1) Frequency of culture-bound unit;

2) Importance of the unit within the whole text;

3) Pretranslated / established equivalent;

4) Overall compatibility of strategies within the novel;

5) Proximity / remoteness of unit to target culture;

6) Translation skill;

7) Time-limit;

8) Research opportunities (i.e., not only whether the translator has access to Internet but whether the item in question is researchable on the Internet);

9) Editors' choices;

10) Whether it is a series (like Bridget Jones);

11) Previous examples from the same author / genre and many other factors.

Several of these factors can be studied (such as frequency of culture-bound unit) whereas most of them cannot be known by the researcher (i.e., translation skill) but these and many others affect the translator's choice as we see it reflected in the novel. Apart from these, my other observations and comments may be summarized as my concluding remarks in the following paragraphs.

From this study, I have deduced and verified the thought that bestsellers are translated into Turkish hastily and in a rather off-hand manner without paying attention to the details of meaning which would help readers learn about the source culture surrounding the story in the book. The primary aim of bestsellers may not be to provide the reader with cultural information per se, but since the reader chooses to read a translated book whether it is classical literature or popular fiction, the translator should try to avoid mistranslations and pay more attention to the culturespecific words and collocations. The translator must also remember that bestsellers are generally assumed to be read by more people than, for example, literary novels. Sometimes a bestseller may be the only source where one learns about the other. Thus, even misconceptions or prejudices between cultures may arise due to mistranslations. To avoid this, translators may try to explain to the publishing houses or editors that high quality translations are more profitable in the long run than translations with certain time limitations undertaken recklessly. I firmly believe the general readership would prefer publishing houses working with trained and qualified translators who respect their readers since the product would be readable and probably more enjoyable. I convinced the two publishing houses I am working with at present that being more flexible about the deadlines even in translating bestsellers will help me translate better and this, in the end, adds to their stable customer profile.

Last but not least, I have tried to show that the translation of bestsellers is also a subject worth studying and requires more attention from academic circles. It has 
specific characteristics and limitations and thus may provide data as well as new perspectives to translation theory. Further research and more comprehensive data are required to be able to make generalizations and suggest solutions to the problems encountered. If and when the academic circles choose to include studies on popular fiction from books on translation theory, translation anthologies, translation dictionaries and course books on translation, new research and data will serve to feed the domain.

\section{NOTES}

1. Two bestselling detective novels written by American authors, namely Stuart Woods and Peri O'Shaughnessy and their translations into Turkish have been analysed in the study and it is found out that some of the problems that the translator may face during the translation of these novels are as follows: a) proper names with unique referents; b) idioms; c) informal address terms; d) reactives, emphatics and ideophones; e) acronyms; and f) clippings. In order to overcome these problems, the translator has to carry out research on the Internet to find the relevant meanings. Next, she / he must decide on the appropriate translation strategy and whether to preserve the foreign cultural item (especially in instances of proper names) or the original form (idiom, acronym, reactive). The translator must be aware of the translated literary convention of the genre concerned, reflect the cultural aura of the original as far as possible, use informal spoken language, not underestimate / overestimate the readers capabilities, not make unnecessary deletions or give long explanations, and may contact the writer (if possible) and ask for help in some problematic cases.

2. Fielding, Helen (2001): Bridget Jones's Diary. London: Picador. Fielding, Helen (2004): Bridget Jones’un Günlüğ̈̈. (Translated by Dost Körpe and Handan HAZAR) İstanbul: Gendaş Kültür.

3. Hornby, Nick (2000): About a Boy. London: Penguin Books.

Hornby, Nick (2005): Bir ErkekHakkında. (Translated by Esin EşKınat) İstanbul: Sel Yayıncılık.

4. Rankin, Ian (1998): Black \& Blue. London: Orion Books Ltd.

Rankin, Ian (2006): Siyah ve Mavi. (Translated by Zeynep Perker) İstanbul: Vatan Kitap.

\section{REFERENCES}

Aixela, Javier Franco (1996): Culture-Specific Items in Translation. In: Román Álvarez and M. Carmen-África Vidal, eds. Translation, Power, Subversion. Clevedon: Multilingual Papers, 52-78.

Bahumaid, Showqi (2006): Collocation in English-Arabic Translation. Babel. 52(2):133-152.

BAKER, Mona (1992): In Other Words: a coursebook on translation. London: Routledge.

Bloom, Clive (2002): Bestsellers: Popular Fiction Since 1900. New York: Palgrave MacMillan.

Chesterman, Andrew and Wagner, Emma (2002): Can Theory Help Translators? A Dialogue Between the Ivory Tower and the Wordface. Manchester: St. Jerome.

DinçKan, Yeşim (2006): Translating the Bestseller. H.Ü. MTB Çeviribilim ve Uygulamaları. 16: 107-121.

Eco, Umberto (2001): Experiences in Translation. (Translated by Alastair McEwen) Toronto: University of Toronto Press.

Hinckley, Karen and Hinckley, Barbara (1989): American Best Sellers: A Reader's Guide to Popular Fiction. Bloomington: Indiana University Press.

Katan, David (2004): Translating Cultures: An Introduction for Translators, Interpreters, and Mediators. Manchester: St Jerome.

Kurultay, Turgay, Ayav, Özlem, DolanoĞLu, Sosi, et al. (1992): Sayı verilerle Türkiye'de Çeviri Dergileri: Ülkemizde basılan kitaplar üzerine birkaç sayısal veri. Metis Çeviri. 20/21: 135150.

Linder, Daniel (2001): Translating Irony in Popular Fiction: Raymond Chandler's The Big Sleep. Babel. 47(2):97-108. 
Mercer, Deborah (2001): The Translation of the Unterhaltungsroman. Ph.D. thesis, unpublished. Norwich, University of East Anglia.

Merriam Webster's Readers Handbook: Your Complete Guide to Literary Works (1997): Springfield: Merriam Webster.

Newmark, Peter (1988): A Textbook of Translation. New York: Prentice Hall.

PaIzIs, George (1998): Category Romances: Translation, Realism and Myth. The Translator. $4(1): 1-24$.

Radford, Jean, ed. (1986): The Progress of Romance: The Politics of Popular Fiction. London: Routledge.

Snell-Hornby, Mary (2006): The Turns of Translation Studies. Amsterdam: John Benjamins.

Venuti, Lawrence (1995): The Translator's Invisibility. London: Routledge.

Venuti, Lawrence (1998): The Scandals of Translation: Towards an ethics of difference. London: Routledge.

Venuti, Lawrence (2004): The Translation Studies Reader. London: Routledge.

\section{APPENDIX}

\section{The asterisk indicates examples cited in the text.}

\section{Translation using a loan collocation}

a. Some sort of Mary Poppins person* Mary Poppins gibi (lit.: like Mary Poppins)

(Bridget Jones's Diary, 8) (Bridget Jones’un Günlüğü, 18)

b. a child of Cosmopolitan culture

(Bridget Jones's Diary, 59) Cosmopolitan kültürünün çocuklarından biriyim (lit.: a child of Cosmopolitan culture)

(Bridget Jones’un Günlüğü, 69)

\section{Literal Translation}
a. Bank Holiday ${ }^{\star}$ Banka Tatili
b. Mrs Iron Knickers Bayan Demir Don
c. tea party (Bridget Jones's Diary, 69) çay partisi
d. homeless people evsizler (Siyah ve Mavi, 270)

(Bridget Jones's Diary, 123) (Bridget Jones'un Günlüğ̈̈̈, 131)

(Bridget Jones's Diary, 37) (Bridget Jones'un Günlüğ̈̈, 47)

(Bridget Jones’un Günlüğü, 78) (Black \& Blue, 322)

\section{Footnote}

a. Shepherd's pie (Bridget Jones's Diary, 82) Shepherd's pie

\section{Footnote:}

Pişmiş et ve patatesleri tepsiye dizip firına vererek hazırlanan bir yemek. (It is a meal prepared by baking cooked meat and potatoes in the oven.) 


\section{Translation by paraphrase}

a. August Bank Holiday Ağustos ayında bankaların bile tatilde olduğu bir günde (lit.: a day in August when even the banks are on holiday)

(Bridget Jones'un Günlüğ̈̈, 18)

b. chip shop* (Black \& Blue, 14) balık ve cips dükkanı (lit.: fish and crisp shop)

(Siyah ve Mavi, 17)

c. Christmas cards Noel ve yeni yıl kartları

(Bridget Jones's Diary, 8) (lit.: Christmas and New Year cards)

(Bridget Jones's Diary, 264)

d. self-help book insanlara ögüt veren kitaplardan bir tane (lit.: one of the books which gives advice to people)

(Bridget Jones’un Günlüğ̈̈, 70)

\section{Translation by a collocation of similar meaning but dissimilar form}
a. spring roll
çin böreği
(lit.: Chinese pie)
b. April Fool's Day joke
1 Nisan sakası
(lit.: $1^{\text {st }}$ of April joke)

(About a Boy, 231)

(Bir Erkek Hakkında, 188)

(About a Boy, 229)

(Bir Erkek Hakkında, 186)

\section{Neutralization}

a. by their Christian Names

(Bridget Jones's Diary, 55)

sadece isimleriyle

(lit. only with their names)

(Bridget Jones'un Günlüğ̈̈, 65)

b. communal changing room

(Bridget Jones's Diary, 122)

bir mağazanın soyunma odası

(lit.: a changing room)

(Bridget Jones'un Günlüğ̈̈, 130)

c. a pint of beer

(Bridget Jones's Diary, 159)

bir kutu bira

(lit.: a can of beer)

(Bridget Jones'un Günlüğ̈̈, 165)

d. Merry Christmas

(Bridget Jones's Diary, 305)

İyi yıllar

(lit.: Happy New Year)

(Bridget Jones'un Günlüğ̈̈, 306)

e. Christmas cards

(Bridget Jones's Diary, 265)

Yılbaşı kartları

(lit.: New Year Cards)

(Bridget Jones'un Günlüğ̈̈, 296)

f. shadow cabinet

(Bridget Jones's Diary, 191)

kabine

(lit.: cabinet)

(Bridget Jones'un Günlüğ̈̈, 197)

g. pre-cinema fast-food meals

(About a Boy, 303)

Sinema öncesi öğle yemeklerinden

birinde

(lit.: pre-cinema meals)

(Bir Erkek Hakkında, 244) 
$\begin{array}{lc}\text { h. a charity shop* } & \text { (Black \& Blue, 11) } \\ \text { bir dükkan } & \\ \text { (lit.: a shop) } & \text { (Siyah ve Mavi, 14) } \\ \text { i. } \begin{array}{l}\text { bed and breakfast } \\ \text { pansiyon }\end{array} & \text { (Black \& Blue, 197) } \\ \text { (lit.: hostel) } & \text { (Siyah ve Mavi, 165) }\end{array}$

\section{Translation by cultural substitution}
a. sex-god seks tanrıçası
(sex-goddess)
(Bridget Jones's Diary, 82)
(Bridget Jones'un Günlüğü, 91)
b. single mother* yalnız bir anneyim (a mother who is alone)
(Bridget Jones's Diary, 117)
(Bridget Jones’un Günlüğ̈̈, 125)
c. single mother dul bir anne (a widowed mother)
(About a Boy, 22)
(Bir Erkek Hakkında, 23)
d. single father* dul bir baba (a widowed father)
(About a Boy, 22)
(Bir Erkek Hakkında, 32)
e. single parents' group boşanmıs ebeveynler kulübü (a club for divorced parents)
(About a Boy, 36)
(Bir Erkek Hakkında, 33)

\section{Omission}
a. Big Apple*
b. a happy hour
a. karaoke night

(Bridget Jones's Diary, 101) (Bridget Jones'un Günlüğ̈̈, 109) (Black \& Blue, 185) (Siyah ve Mavi, 157)

(Black \& Blue, 185) (Siyah ve Mavi, 157)

\section{Mistranslation}
a. four-poster bed dört kişilik yatak (a bed for four people)
b. smoked salmon* somon balığ 1 (salmon fish)
c. smoked salmon alabalık buğulaması (smoked trout fish)
d. terraced housing terasli evler (houses with terraces)

(Bridget Jones's Diary, 307)

(Bridget Jones’un Günlüğ̈̈, 308)

(Bridget Jones's Diary, 125)

(Bridget Jones’un Günlüğü, 133)

(Bridget Jones's Diary, 300)

(Bridget Jones’un Günlüğ̈̈, 302)

(Black \& Blue, 95)

(Siyah ve Mavi, 74) 
e. chip shop

balık ve cips dükkanı

(fish and crisp shop)

f. softball game

beysbol maçı

(baseball match)

g. Bank Holiday

Banka Tatili

(the day which only the banks are closed)
(Black \& Blue, 14)

(Siyah ve Mavi, 17)

(Bridget Jones's Diary, 150)

(Bridget Jones'un Günlüğ̈̈, 156)

(Bridget Jones's Diary, 123)

(Bridget Jones’un Günlüğ̈̈, 131) 